\title{
ANALISIS KINERJA KEUANGAN BANK UMUM SYARIAH DENGAN MENGGUNAKAN METODE RGEC
}

\author{
Oleh: \\ A. Khairuddin dan Achmad \\ Fakultas Dakwah IAI Ibrahimy Situbondo \\ Fakultas Ekonomi dan Bisnis Islam IAI Ibrahimy Situbondo \\ akhair68@gmail.com \& amamat75@gmail.com
}

\begin{abstract}
One of the quality management concepts that can be applied in pesantren is total quality service (TQS). Total Quality Service is a modern management concept of study that focuses of five areas, 1) customer focus, 2) total involvement, 3) measurement, 4) systematic support, and 5) connous improvement.

Pesantren education institute is said quality meaning refers on resulting product quality by pesantren, one that covers; a lot of students have achievement well at academic area and also at non academic, mark sense good lead support among pesantren "its customer", output and outcame pesantren corresponds to expectation, and is still a lot of again. Pesantren education quality in this perspective can also be seen of two things, which are points on education process and education result. Process quality education pointed out by components exhaustive involvement pesantren in education activity. Education result can be seen of insofar which pesantren grad have been interesting and personality corresponds to pesantren vision and mission.
\end{abstract}

Key Words : Kinerja Keuangan, Bank Umum Syariah, RGEC

\section{A. Pendahuluan}

Perkembangan bank syariah di Indonesia diawali dengan terbitnya UU Nomor 7/1992 tentang Perbankan, yang memberi peluang bagi bank umum untuk menjalankan operasional bisnisnya dengan sistem bagi hasil. Pada tahun 1992 inilah berdiri bank syariah pertama, Bank Muamalah Indonesia (BMI). Kemudian tahun 1998, pemerintah menyempurnakan kebijakan dual banking system melalui UU Nomor 10/1998 tentang Perbankan sebagai Perubahan atas UU Nomor 7/1992. Eksistensi bank syariah menjadi semakin kokoh sejak terbitnya UU Nomor 21/2008 tentang Perbankan Syariah, yang didalamnya mengatur secara lebih terperinci mulai dari hal perizinan, tata kelola, sampai pembinaan dan pengawasannya. 
Dukungan regulasi dan adanya Fatwa MUI Nomor 1 Tahun 2004 yang menegaskan keharaman bunga bank, mendorong bank syariah di Indonesia berkembang cukup pesat. Dari data Statistik Perbankan Syariah (SPS) per Desember 2016, diketahui bahwa jumlah Bank Umum Syariah (BUS) pada saat ini mencapai 13 bank, Unit Usaha Syariah (UUS) sebanyak 21 unit, dan 167 Bank Pembiayaan Rakyat Syariah (BPRS), dengan total aset sebesar Rp254.184 triliun, meningkat 19,1\% dari nilai aset pada ahir tahun $2015^{1}$.

Pertumbuhan ini bisa disebut sebagai bentuk peningkatan kepercayaan masyarakat terhadap institusi dan produk perbankan syariah. Hal ini harus diimbangi dengan berbagai upaya agar perbankan syariah mampu menjadi lembaga keuangan yang sehat, kuat dan efisien. Diantaranya dengan menerapkan prinsip kehati-hatian dalam menjalankan kegiatan usaha, serta meningkatkan kualitas aset dan manajemennya, baik dalam aspek keuangan maupun kepatuhannya terhadap prinsip syariah.

Sebagai lembaga yang kegiatan usahanya mengandalkan kepercayaan masyarakat, tingkat kesehatan bank harus dipelihara dan ditingkatkan, agar bank dapat beroperasi secara optimal. Kesehatan bank merupakan sarana bagi otoritas pengawas dalam menetapkan strategi dan fokus pengawasan. Terlebih lagi bagi bank syariah yang tumbuh di tengah pesat dan dominannya bank konvensional. Sehingga bank syariah memiliki tantangan dan risiko yang lebih besar dibanding bank konvensional. Institusi bank syariah tidak hanya sebagai organisasi bisnis, tetapi juga sebagai organisasi sosial dan dakwah ${ }^{2}$. Selain harus mematuhi regulasi yang ditetapkan pemerintah, bank syariah juga harus memperhatikan aturan dan norma-norma Islam ${ }^{3}$.

Untuk mengetahui tingkat kesehatan bank, dapat dilakukan dengan menganalisis laporan keuangannya, yaitu melalui penghitungan rasiorasio keuangan. Laporan keuangan dapat berfungsi sebagai alat berkomunikasi antara data-data keuangan dan aktivitas suatu perusahaan

1 Otoritas Jasa Keuangan RI, Statistik Perbankan Syariah - Desember 2016. http://www.ojk.go.id/id/kanal/syariah/data-dan-

statistik/statistikperbankansyariah/default.aspx, diunduh pada tanggal 9 Nopember 2017.

${ }^{2}$ Niswatin, Konsep Dasar Penilaian Kinerja Bank Syariah, (Jakarta: Jurnal Ekonomi dan Manajemen.SIEI, Indonesia Banking School, 2015), hlm. 2.

3 Arcarya dan Diana Yumanita, Bank Syariah: Gambaran Umum, (Jakarta: PPSK Bank Indonesia, 2005), hlm. 4.

$384 \mid$ JURNAL LISAN AL-HAL 
dengan pihak-pihak yang berkepentingan ${ }^{4}$. Laporan keuangan akan menunjukkan kinerja yang telah dicapai bank pada suatu periode tertentu ${ }^{5}$. Dari laporan keuangan akan terbaca kondisi bank yang sesungguhnya, termasuk kelemahan dan kekuatan yang dimiliki ${ }^{6}$. Dengan analisis laporan keuangan dapat diketahui rasio rentabilitas dan permodalan yang merupakan hasil dari penerapan manajemen risiko dan GCG yang baik ${ }^{7}$. Sehingga laporan keuangan menjadi salah satu sumber informasi yang mendapat perhatian investor dalam pengambilan keputusan investasi ${ }^{8}$.

Penilaian tingkat kesehatan bank, semula menggunakan alat analisis CAMEL (meliputi Capital, Asset quality, Management, Earning, Liquidity). Kemudian ditambah dengan Sensitivity to Market Risk, sehingga istilahnya berubah menjadi metode CAMELS (berdasarkan Peraturan Bank Indonesia nomor 9/1/PBI/2007 tentang Sistem Penilaian Tingkat Kesehatan Bank Umum Berdasarkan Prinsip Syariah). Terakhir, Bank Indonesia menetapkan metode RGEC sebagai faktor untuk menilai kesehatan bank, yaitu melalui Peraturan Bank Indonesia Nomor 13/1/PBI/2011 tentang Penilaian Tingkat Kesehatan Bank Umum. Tetapi penerapan RGEC pada bank syariah baru diberlakukan sejak terbitnya Peraturan Otoritas Jasa Keuangan Nomor 8/PJOK.03/2014 tentang Penilaian Tingkat Kesehatan Bank Umum Syariah dan Unit Usaha Syariah, yang tata cara penilaiannya dijelaskan dalam Surat Edaran OJK Nomor 10/SEOJK/.03/2014.

Melalui RGEC, Bank Indonesia menginginkan agar bank syariah mampu mengidentifikasi permasalahan secara lebih dini, mampu melakukan tindak lanjut perbaikan yang sesuai dan cepat, serta dapat menerapkan Good Corporate Governance dan manajemen risiko yang lebih baik, sehingga bank lebih tahan dalam menghadapi krisis. Penilaian tingkat kesehatan bank pada BUS meliputi penilaian atas faktor Risk Profile, Good Corporate Governance, Rentabilitas (Earning), dan Capital

${ }^{4}$ Munawir, Analisa Laporan Keuangan, Jilid 12, (Yogyakarta: Liberty, 2007), hlm. 2.

${ }^{5}$ Nurlela, et. all. Analisis Perbandingan Kinerja Keuangan pada Perbankan Syariah dengan Perbankan Asing di Indonesia, (Lhokseumawe: Jurnal Visioner dan Strategis, Universitas Malikussaleh, Vol. 1, No. 1, 2012), hlm. 95.

${ }^{6}$ Kasmir, Manajemen Perbankan, (Jakarta: Rajawali Press, 2012), hlm. 68.

${ }^{7}$ Permana, Bayu Aji, Analisis Tingkat Kesehatan Bank berdasarkan Metode CAMELS dan Metode RGEC, (Surabaya: Jurnal Akuntansi UNESA, Vol. 1, No. 1, 2012)

${ }^{8}$ Usman (2009) dalam Nurlela, et.all, Analisis Perbandingan Kinerja Keuangan pada Perbankan Syariah dengan Perbankan Asing di Indonesia, (Lhokseumawe: Jurnal Visioner dan Strategis, Universitas Malikussaleh. Vol. 1, No. 1, 2012), hlm. 96. 
(modal), yang dikenal dengan RGEC. Sedang untuk UUS, cakupan penilaiannya hanya pada faktor Profil Risiko.

Dari gambaran di atas, tulisan ini bertujuan untuk mengetahui kinerja keuangan perbankan syariah dengan menggunakan metode RGEC. Penelitian dibatasi pada 4 BUS yang memiliki jaringan kantor individual paling besar, yaitu: Bank Muamalah Indonesia (BMI), BRI Syariah, Bank Syariah Mandiri (BSM), dan BNI Syariah. Sedangkan faktor RGEC yang akan diteliti, dibatasi pada: (1) faktor Risk Profile hanya pada dua risiko, yaitu: risiko kredit dan risiko likuditas, (2) faktor Earning (rentabilitas), dan (3) faktor Capital (permodalan).

\section{B. Pembahasan}

Penelitian ini menggunakan data sekunder berupa laporan keuangan perusahaan yang diunduh di website resmi perusahaan. Laporan keuangan yang dijadikan sumber data adalah laporan keuangan publikasi tahunan (annual report) masing-masing bank, pada periode tahun 2012 sampai 2016. Tahun awal diberlakukannya metode RGEC atas bank umum, termasuk bank yang menjalankan usaha dengan prinsip syariah.

Untuk mengetahui kinerja bank dapat dilakukan dengan menganalisis laporan keuangan yang dipublikasikan perusahaan. Kinerja bank merupakan gambaran prestasi yang dicapai bank dalam operasionalnya, baik menyangkut aspek pemasaran, keuangan, penghimpunan dan penyaluran dana, teknologi dan SDM. Kinerja keuangan bank merupakan gambaran kondisi keuangan bank pada suatu periode tertentu, yang umumnya diukur dengan indikator kecukupan modal, likuiditas, dan profitabilitas $^{9}$ yang tercermin dalam laporan keuangannya ${ }^{10}$. Penilaian kinerja merupakan unsur terpenting dalam aktivitas manajemen yang berfungsi untuk menilai ketercapaian tujuan organisasi.

Laporan keuangan pada dasarnya adalah hasil proses akuntansi, yang dapat digunakan sebagai alat komunikasi antara data keuangan atau aktivitas suatu perusahaan dengan pihak-pihak yang berkepentingan. Laporan keuangan merupakan salah satu sumber informasi yang digunakan para investor dalam mengambil keputusan investasi. Karena

${ }^{9}$ Umiyati dan Queenindya, Pengukuran Kinerja Bank Syariah dengan Metode RGEC, (Jurnal Akuntansi dan Keuangan Islam. Vol. 2, No. 2, 2015), hlm. 189.

10 Matnin, Kinerja dan Kesehatan Bank Islam, (Bangkalan: Jurnal Dinar Ekonomi Syariah, Universitas Trunojoyo. Vol. 1, No. 1, Agustus 2016), hlm. 5.

$386 \mid$ JURNAL LISAN AL-HAL 
itu, analisis atas laporan dianggap penting sebagai sarana untuk memahami informasi yang terkandung dalam laporan keuangan. Laporan keuangan bank syariah dibagi menjadi 2 bagian, yaitu:

1. Laporan laba keuangan yang menggambarkan fungsi bank Islam sebagai investor, hak, dan kewajibannya. Dengan tidak memandang tujuan bank Islam dari masalah investasinya, apakah ekonomi atau sosial. Laporan keuangan ini meliputi: (a) laporan posisi keuangan atau neraca; (b) laporan laba rugi; (c) laporan arus kas; dan (d) laporan laba ditahan atau perubahan saham pemilik.

2. Laporan keuangan yang menggambarkan peran bank Islam sebagai fiduciary dari dana yang tersedia untuk jasa sosial. Laporan ini meliputi:

(a) laporan sumber dan penggunaan dana zakat dan dana sosial; dan

(b) laporan sumber dan penggunaan dana qardh ${ }^{11}$.

Adapun data yang digunakan dalam pembahasan ini bersumber dari laporan keuangan bank sebagai investor, yang terdiri dari:

1. Data hasil penilaian profil risiko yang tercantum dalam laporan profil risiko pada laporan tahunan bank, meliputi rasio pembiayaan bermasalah atau Non Perfoming Financing (NPF) dan rasio likuiditas bank atau Financing to Deposit Ratio (FDR).

2. Data nilai Return on Asset (ROA) dan Capital Adequacy Ratio (CAR) yang tercatat dalam laporan tahunan publikasi masing-masing bank.

Sebagai lembaga keuangan yang tumbuh di tengah pesatnya bank konvensional, maka kesehatan bank syariah harus dipelihara dan ditingkatkan. Kesehatan bank merupakan kemampuan bank untuk melakukan kegiatan operasional perbankan secara normal dan mampu memenuhi kewajiban dengan baik, dengan cara-cara sesuai peraturan perbankan yang berlaku ${ }^{12}$. Bank yang sehat adalah bank yang mampu menjaga kepercayaan masyarakat, dapat menjalankan fungsi intermediasi, dapat membantu kelancaran lalu lintas pembayaran, serta dapat digunakan pemerintah untuk melaksanakan berbagai kebijakan, terutama kebijakan moneter ${ }^{13}$. Bank dikategorikan berada dalam kondisi sangat sehat, apabila keadaan bank dinilai mampu untuk menghadapi pengaruh 235

${ }^{11}$ Muhammad, Manajemen Bank Syariah, (Yogyakarta: UPP AMP YKPN, 2005), hlm.

${ }^{12}$ Lasta, Heidy Arrvida, dkk., Analisis Tingkat Kesehatan Bank dengan Menggunakan Pendekatan RGEC, (Malang: Jurnal Administrasi Bisnis, Universitas Brawijaya. Vol. 13, No. 2, 2014), hlm. 2.

13 Fitriana, dkk., Tingkat Kesehatan Bank BUMN Syariah dengan Bank BUMN Konvensional Metode RGEC (Risk Profile, Good Corporate Governance, Earning, dan Capital), (Pekalongan: Jurnal Ekonomi dan Bisnis. Vol. 17, No. 2, 2015), hlm. 1-2. 
negatif yang signifikan dari perubahan kondisi bisnis dan faktor eksternal lainnya. Hasil penilaian kesehatan bank, selanjutnya akan menjadi sarana bagi pihak otoritas keuangan untuk menetapkan strategi dan fokus pengawasan.

Pada pasal 2 POJK nomor 8/POJK.03/201414, ditegaskan bahwa bank wajib memelihara dan/atau meningkatkan tingkat kesehatan bank dengan menerapkan prinsip kehati-hatian, prinsip syariah, manajemen risiko dalam melaksanakan kegiatan usaha. Tingkat kesehatan bank adalah hasil penilaian atas kondisi bank yang dilakukan berdasarkan pendekatan risiko (risk based bank rating), termasuk risiko yang terkait dengan penerapan prinsip syariah.

Dengan pesatnya perkembangan industri di sektor perbankan, serta adanya perubahan kompleksitas usaha, profil risiko dan metodologi penilaian kondisi bank secara internasional, mendorong Bank Indonesia untuk merefisi instrumen penilaian tingkat kesehatan bank dengan metode RGEC. Metode RGEC ini menilai tingkat kesehatan bank atas empat faktor, yaitu Risk Profile, Good Corporate Governance, Rentabilitas (Earning), dan Capital.

Penilaian profil risiko merupakan penilaian terhadap risiko inhern dan kualitas penerapan manajemen risiko atas risiko operasional bank. Penilaian terhadap faktor Good Corporate Governance merupakan penilaian atas pelaksanaan prinsip-prinsip GCG. Penilaian terhadap faktor rentabilitas (earning) meliputi penilaian atas kinerja rentabilitas, sumbersumber rentabilitas, dan stabilitas rentabilitas (sustainability learning). Sedangkan penilaian atas faktor permodalan (capital) dimaksudkan untuk mengukur tingkat kecukupan permodalan dan pengelolaan permodalan.

\section{Penilaian Profil Risiko (Risk Profil)}

Penilaian atas profil risiko dilakukan untuk mengetahui kualitas penerapan manajemen risiko terhadap 10 risiko operasional bank, mulai dari: risiko kredit, risiko pasar, risiko likuiditas, risiko operasional, risiko hukum, risiko stratejik, risiko kepatuhan, risiko reputasi, risiko imbal hasil, dan risiko investasi. Pembahasan dalam tulisan ini dibatasi pada Risiko Kredit (Non Perfoming Financing/NPF) dan risiko likuiditas (Financing to Deposit Ratio/FDR).

\footnotetext{
14 Peraturan Otoritas Jasa Keuangan RI Nomor 8/POJK.03/2014 tentang Penilaian Tingkat Kesehatan Bank Umum Syariah dan Unit Usaha Syariah

388 JURNAL LISAN AL-HAL
} 


\section{a. Risiko Kredit (Non Perfoming Financing/NPF)}

Risiko kredit adalah risiko akibat kegagalan debitur atau pihak lain dalam memenuhi kewajiban kepada bank. Risiko kredit umumnya terdapat pada seluruh aktifitas bank yang kinerjanya bergantung pada kinerja pihak lawan (counterparty), penerbit (issuer), atau kinerja penyedia dana (borrower) ${ }^{15}$. Penghitungan risiko kredit menggunakan rumus sebagai berikut:

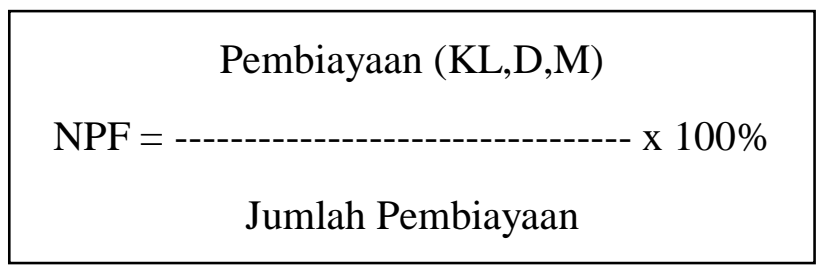

Sedang kriteria penilaian peringkatnya yaitu: 16

Peringkat $1 \quad:$ NPF $/$ NPL $<2 \%$

Peringkat $2 \quad: 2 \%<\mathrm{NPF} / \mathrm{NPL}<5 \%$

Peringkat $3 \quad: 5 \%<\mathrm{NPF} / \mathrm{NPL}<8 \%$

Peringkat $4 \quad: 8 \%<\mathrm{NPF} / \mathrm{NPL}<12 \%$

Peringkat $5 \quad$ : NPF/NPL $>12 \%$

Urutan peringkat faktor Profil Risiko yang lebih kecil mencerminkan semakin rendahnya risiko yang dihadapi bank ${ }^{17}$.

Rasio NPF adalah rasio Pembiayaan Bermasalah terhadap Total Pembiayan yang disalurkan bank. Tujuannya adalah untuk mengukur tingkat permasalahan pembiayaan yang dihadapi oleh bank. Semakin tinggi rasio ini, menunjukkan bahwa kualitas pembiayaan bank syariah semakin buruk. ${ }^{18}$ Dari hasil analisis atas dokumen laporan tahunan empat BUS, diperoleh rasio NPF sebagai berikut:

${ }^{15}$ Surat Edaran Bank Indonesia Nomor 13/24/DPNP tahun 2011 tentang Penilaian Tingkat Kesehatan Bank Umum

16 Tim Penyusun, Kodifikasi Peraturan Bank Indonesia: Kelembagaan, Penilaian Tingkat Kesehatan Bank, (Jakarta: Pusat Riset dan Edukasi Bank Sentral, 2012), hlm. 179 Bank Umum

17 SE BI nomor 13/24/DPNP tahun 2011 tentang Penilaian Tingkat Kesehatan

18 Tim Penyusun, Kodifikasi Peraturan Bank Indonesia: Kelembagaan, Penilaian Tingkat Kesehatan Bank. (Jakarta: Pusat Riset dan Edukasi Bank Sentral, 2012), hlm. 79.

JURNAL LISAN AL-HAL 389 


\begin{tabular}{|c|l|c|c|c|c|c|l|}
\hline No & \multicolumn{1}{|c|}{ BUS } & 2012 & 2013 & 2014 & 2015 & 2016 & Peringkat \\
\hline 1 & $\begin{array}{l}\text { Bank } \\
\text { Muamalah }\end{array}$ & $1,81 \%$ & $1,56 \%$ & $4,85 \%$ & $4,20 \%$ & $1,40 \%$ & $\begin{array}{l}\text { Peringkat } \\
1\end{array}$ \\
\hline 2 & $\begin{array}{l}\text { Bank } \\
\text { Syariah } \\
\text { Mandiri }\end{array}$ & $1,14 \%$ & $2,29 \%$ & $4,29 \%$ & $4,05 \%$ & $3,13 \%$ & $\begin{array}{l}\text { Peringkat } \\
2\end{array}$ \\
\hline 3 & $\begin{array}{l}\text { Bank BRI } \\
\text { Syariah }\end{array}$ & $2,09 \%$ & $3,26 \%$ & $3,65 \%$ & $3,89 \%$ & $3,19 \%$ & $\begin{array}{l}\text { Peringkat } \\
2\end{array}$ \\
\hline 4 & $\begin{array}{l}\text { Bank BNI } \\
\text { Syariah }\end{array}$ & $1,42 \%$ & $1,13 \%$ & $1,04 \%$ & $1,46 \%$ & $1,64 \%$ & $\begin{array}{l}\text { Peringkat } \\
1\end{array}$ \\
\hline Rata-Rata : & $\mathbf{1 , 6 2 \%}$ & $\mathbf{2 , 0 6 \%}$ & $\mathbf{3 , 4 6 \%}$ & $\mathbf{3 , 4 0 \%}$ & $\mathbf{2 , 3 4 \%}$ & \\
\hline Rasio SPS-BUS : & $2,22 \%$ & $2,62 \%$ & $3,38 \%$ & $3,19 \%$ & $2,17 \%$ & \\
\hline
\end{tabular}

Data di atas menunjukkan Bank Muamalah Indonesia (BMI) dan Bank BNI Syariah memiliki peringkat yang lebih baik dari Bank Syariah Mandiri (BSM) dan Bank BRI Syariah. Dimana jumlah Pembiayaan Bermasalahnya (NPF) berada di bawah 2\%, atau di bawah angka rata-rata keseluruhan Bank Umum Syariah (BUS).

BMI berhasil menekan rasio NPF-nya yang sempat di atas 4\% dalam dua tahun sebelumnya, menjadi 1,40\%. Demikian halnya dengan Bank Syariah Mandiri (BSM) dan BRI Syariah, juga mampu menurunkan rasio NPF-nya dari tahun sebelumnya. Sedangkan Bank BNI Syariah, meski rasio NPF-nya meningkat dari tahun sebelumnya, tetapi prestasi BNI Syariah dalam 5 tahun terakhir adalah mampu menekan rasio NPF di bawah $2 \%$ atau di bawah rata-rata NPF BUS.

\section{b. Risiko Likuiditas (Financing to Deposit Ratio/FDR)}

Risiko likuiditas adalah risiko akibat ketidakmampuan bank untuk memenuhi kewajiban yang jatuh tempo dari sumber pendanaan arus kas atau dari aset likuid berkualitas tinggi yang dapat diagunkan, tanpa mengganggu aktivitas dan kondisi keuangan bank. Likuiditas merupakan kemampuan perusahaan untuk membayar hutang-hutang jangka pendek, maksimal satu tahun, dengan sejumlah aktiva lancar yang dimiliki ${ }^{19}$. Semakin tinggi nilai rasio ini, menunjukkan perusahaan memiliki margin keamanan yang lebih besar untuk menutup kewajiban jangka pendeknya. Rendahnya rasio ini mengindikasikan bahwa bank memiliki kelebihan

19 Abdullah, M. Faisal, Dasar Manajemen Keuangan, (Yogyakarta: UMM Press, 2002), hlm. 40.

$390 \mid$ JURNAL LISAN AL-HAL 
likuiditas. Sehingga rasio likuiditas menunjukkan efektivitas fungsi mediasi bank ${ }^{20}$.

Bank dikatakan likuid, apabila bank dapat memenuhi kewajiban hutang-hutangnya, dapat membayar kembali semua depositonya, serta dapat memenuhi permintaan kredit yang diajukan dengan tanpa adanya penangguhan ${ }^{21}$. Likuditas bank diukur dengan rasio berikut:

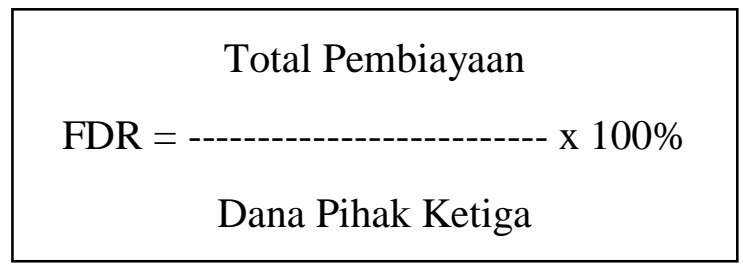

FDR adalah rasio Pembiayaan terhadap Dana Pihak Ketiga. Rasio ini bertujuan untuk mengukur kemampuan bank untuk membayar hutanghutang jangka pendek, maksimal satu tahun, dengan sejumlah aktiva lancar yang dimiliki. Sedangkan kriteria dalam penilaian peringkatnya yaitu sebagai berikut:

$$
\begin{array}{ll}
\text { Peringkat 1 } & : 50 \%<\text { FDR } / \text { LDR }<75 \% \\
\text { Peringkat 2 } & : 75 \%<\text { FDR/LDR }<85 \% \\
\text { Peringkat 3 } & : 85 \%<\text { FDR/LDR }<100 \% \\
\text { Peringkat 4 } & : 100 \%<\text { FDR/LDR }<120 \% \\
\text { Peringkat 5 } & : \text { FDR/LDR }>120 \%
\end{array}
$$

Dari dokumen laporan tahunan empat BUS, diperoleh rasio FDR sebagai berikut:

\begin{tabular}{|c|c|c|c|c|c|c|l|}
\hline No & BUS & 2012 & 2013 & 2014 & 2015 & 2016 & Peringkat \\
\hline 1 & $\begin{array}{l}\text { Bank } \\
\text { Muamalah }\end{array}$ & $94,15 \%$ & $99,99 \%$ & $84,14 \%$ & $90,30 \%$ & $95,13 \%$ & $\begin{array}{l}\text { Peringkat } \\
3\end{array}$ \\
\hline 2 & $\begin{array}{l}\text { Bank } \\
\text { Syariah } \\
\text { Mandiri }\end{array}$ & $94,40 \%$ & $89,37 \%$ & $82,13 \%$ & $81,99 \%$ & $79,19 \%$ & $\begin{array}{l}\text { Peringkat } \\
2\end{array}$ \\
\hline 3 & $\begin{array}{l}\text { Bank BRI } \\
\text { Syariah }\end{array}$ & $103,0 \%$ & $102,7 \%$ & $93,90 \%$ & $84,16 \%$ & $81,42 \%$ & $\begin{array}{l}\text { Peringkat } \\
2\end{array}$ \\
\hline 4 & $\begin{array}{l}\text { Bank BNI } \\
\text { Syariah }\end{array}$ & $84,99 \%$ & $97,86 \%$ & $92,60 \%$ & $91,94 \%$ & $84,57 \%$ & $\begin{array}{l}\text { Peringkat } \\
2\end{array}$ \\
\hline Rata-Rata : & $\mathbf{9 4 , 1 5 \%}$ & $\mathbf{9 7 , 4 8 \%}$ & $\mathbf{8 8 , 1 9 \%}$ & $\mathbf{8 7 , 1 0 \%}$ & $\mathbf{8 5 , 0 8 \%}$ & \\
\hline Rasio SPS-BUS : & $100,0 \%$ & $100,3 \%$ & $86,66 \%$ & $88,03 \%$ & $86,27 \%$ & \\
\hline
\end{tabular}

20 Nurwaty, Etty, dkk., Umur dan Kinerja Perusahaan: Studi Empiris Perbankan Syariah di Indonesia, (Bandung: Research and Knowledge, School of Business and Management. Institut Teknologi Bandung, 2014), hlm. 179

${ }^{21}$ Agnes, Sawir, Analisis Kinerja Keuangan dan Perencanaan Keuangan Perusahaan, (Jakarta: PT. Gramedia Pustaka Utama, 2005), hlm. 28. 
Dari tabel di atas, Bank Muamalah Indonesia memiliki rasio FDR yang lebih tinggi dibanding BSM, BRI Syariah, dan BNI Syariah, atau di atas rasio rata-rata FDR BUS. Hal ini menunjukkan bahwa BMI memiliki likuiditas yang lebih baik untuk memenuhi seluruh kewajiban jangka pendek. Bahkan, rasio FDR BMI mengalami peningkatan dalam tiga tahun terahir. Berbeda dengan BSM, BRI Syariah dan BNI Syariah yang mengalami penurunan likuiditas dalam 3 tahun terakhir.

\section{Penilaian Rentabilitas/Earning (Return On Asset/ROA)}

Rentabilitas adalah kemampuan bank dalam menghasilkan laba atau keuntungan ${ }^{22}$. Rentabilitas diukur berdasarkan Return On Asset (ROA). ROA merupakan alat untuk menganalisis tingkat efisiensi usaha dan profitabilitas yang dicapai oleh bank ${ }^{23}$. ROA menjadi indikator yang menunjukkan kemampuan manajemen dalam mengelola aset-aset untuk memperoleh keuntungan. ROA menggambarkan bagaimana bank dapat mengkonversi asetnya ke dalam laba bersih ${ }^{24}$. Sehingga semakin besar ROA suatu bank, semakin besar pula tingkat laba yang dicapai bank ${ }^{25}$ dan semakin baik pula posisi bank tersebut dari sisi penggunaan aset.

ROA menunjukkan besarnya laba yang diperoleh bank terhadap rata-rata total aset. ROA merupakan indikator yang banyak diamati oleh para pemegang saham dan investor untuk mengukur kemampuan bank dalam memperoleh laba yang dikaitkan dengan pembagian deviden. ROA dirumuskan sebagai berikut:

$$
\begin{gathered}
\text { Laba Bersih } \\
\text { ROA }=\text {---------------- } \text { x 100\% } \\
\text { Total Aset } \\
\hline
\end{gathered}
$$

22 Munawir, Analisa Laporan Keuangan, (Yogyakarta: Liberty, 2002), hlm. 245.

23 Harahap, Sofyan Syafri, Analisis Kritis Atas Laporan Keuangan, (Jakarta: Raja Grafindo Persada, 2007), hlm. 304.

24 Nurwaty, Etty, dkk., Umur dan Kinerja Perusahaan: Studi Empiris Perbankan Syariah di Indonesia, (Bandung: Research and Knowledge, School of Business and Management. Institut Teknologi Bandung, 2014), hlm. 178.

25 Sugari, Bella Puspita, dkk., Analisis Perbandingan Tingkat Kesehatan Bank Syariah dan Konvensional dengan Menggunakan Metode GREC (Risk Profile, GCG, Earnings, dan Capital), (Purwokerto: Jurnal Ekonomi Bisnis dan Akuntansi. Universitas Jenderal Sudirman, 2015), hlm. 10.

$$
392 \mid \text { JURNAL LISAN AL-HAL }
$$


Penilaian faktor rentabilitas (earning) meliputi evaluasi terhadap kinerja rentabilitas, sumber-sumber rentabilitas, dan sustainability rentabilitas dengan mempertimbangkan aspek tingkat, trend, struktur, dan stabilitas serta manajemen rentabilitas, baik melalui analisis aspek kuantitatif maupun kualitatif. Adapun kriteria penilaian peringkatnya sebagai berikut: 26

Peringkat $1 \quad$ : ROA $>1,5 \%$

Peringkat $2 \quad: 1,25 \%<\mathrm{ROA}<1,5 \%$

Peringkat $3: 0,5 \%<\mathrm{ROA}<1,25 \%$

Peringkat $4: 0 \%<\mathrm{ROA}<0,5 \%$

Peringkat 5 : ROA $<0 \%$

Urutan peringkat faktor Rentabilitas yang lebih kecil mencerminkan kondisi rentabilitas bank yang lebih baik ${ }^{27}$.

ROA adalah rasio imbal hasil atas rata-rata aset. Tujuannya untuk mengukur kebersilan manajemen dalam menghasilkan laba. Semakin kecil rasio ini maka mengindikasikan kurangnya kemampuan manajemen dalam hal mengelola aktiva untuk meningkatkan pendapatan dan/atau menekan biaya. ${ }^{28}$ Dari hasil analisis atas dokumen laporan tahunan empat BUS, diperoleh rasio ROA sebagai berikut:

\begin{tabular}{|c|l|c|c|c|c|c|l|}
\hline No & \multicolumn{1}{|c|}{ BUS } & 2012 & 2013 & 2014 & 2015 & 2016 & Peringkat \\
\hline 1 & Bank Muamalah & $1,54 \%$ & $0,50 \%$ & $0,17 \%$ & $0,20 \%$ & $0,22 \%$ & $\begin{array}{l}\text { Peringkat } \\
4\end{array}$ \\
\hline 2 & $\begin{array}{l}\text { Bank Syariah } \\
\text { Mandiri }\end{array}$ & $2,25 \%$ & $1,53 \%$ & $0,04 \%$ & $0,56 \%$ & $0,59 \%$ & $\begin{array}{l}\text { Peringkat } \\
3\end{array}$ \\
\hline 3 & $\begin{array}{l}\text { Bank BRI } \\
\text { Syariah }\end{array}$ & $0,88 \%$ & $1,15 \%$ & $0,08 \%$ & $0,77 \%$ & $0,95 \%$ & $\begin{array}{l}\text { Peringkat } \\
3\end{array}$ \\
\hline 4 & $\begin{array}{l}\text { Bank BNI } \\
\text { Syariah }\end{array}$ & $1,48 \%$ & $1,37 \%$ & $1,27 \%$ & $1,43 \%$ & $1,44 \%$ & $\begin{array}{l}\text { Peringkat } \\
2\end{array}$ \\
\hline \multicolumn{2}{r|}{ Rata-Rata : } & $\mathbf{1 , 5 4 \%}$ & $\mathbf{1 , 1 4 \%}$ & $\mathbf{0 , 3 7 \%}$ & $\mathbf{0 , 7 4 \%}$ & $\mathbf{0 , 8 0 \%}$ & \\
\hline & Rasio SPS-BUS : & $2,14 \%$ & $2,00 \%$ & $0,41 \%$ & $0,49 \%$ & $0,63 \%$ & \\
\hline
\end{tabular}

Data di atas menunjukkan bahwa manajemen Bank BNI Syariah memiliki kemampuan lebih baik dalam mengelola aktiva/aset untuk menghasilkan laba, dibanding tiga bank umum syariah lainnya (BMI, BSM,

26 Tim Penyusun, Kodifikasi Peraturan Bank Indonesia: Kelembagaan, Penilaian Tingkat Kesehatan Bank, (Jakarta: Pusat Riset dan Edukasi Bank Sentral, 2012), hlm. 184. Bank Umum

27 SE BI nomor 13/24/DPNP tahun 2011 tentang Penilaian Tingkat Kesehatan

28 Tim Penyusun, Kodifikasi Peraturan Bank Indonesia: Kelembagaan, Penilaian Tingkat Kesehatan Bank, (Jakarta: Pusat Riset dan Edukasi Bank Sentral, 2012), hlm. 184. 
dan BRI Syariah). ROA Bank BNI Syariah berada di atas rata-rata ROA keseluruhan BUS. Meski demikian, secara umum keempat BUS ini berhasil meningkatkan ROA dari tahun 2015.

\section{Penilaian Permodalan (Capital Adequacy Ratio/CAR)}

Penilaian capital merupakan penilaian untuk mengetahui tingkat kecukupan dan pengelolaan permodalan ${ }^{29}$. Permodalan adalah hak kepemilikan pemilik perusahaan atas kekayaan bank (aktiva bersih). Permodalan diukur dengan Capital Adequacy Ratio (CAR).

CAR adalah besarnya jumlah kecukupan modal minimum yang dibutuhkan untuk menutupi risiko kerugian yang mungkin timbul dari penanaman aktiva-aktiva yang mengandung risiko ${ }^{30}$ (kredit, penyertaan, surat berharga, tagihan pada bank lain), yang dibiayai dari modal sendiri atau dari sumber-sumber di luar bank, seperti dana masyarakat atau pinjaman (utang) ${ }^{31}$. CAR merupakan rasio yang menunjukkan sejauhmana kemampuan permodalan bank untuk meminimalisir risiko kegagalan kredit yang mungkin terjadi. Semakin tinggi angka rasio CAR, maka bank tersebut semakin sehat.

Dalam melakukan perhitungan permodalan, harus mengacu pada ketentuan Bank Indonesia yang mengatur tentang Kewajiban Penyediaan Modal Minimum (KPMM). Dalam Peraturan BI nomor 10/15/PBI/200832, disebutkan bahwa setiap bank wajib memenuhi kewajiban penyediaan modal minimum sebesar 8\% dari Aktiva Tertimbang Menurut Risiko (ATMR). Selain itu, dalam melakukan penilaian kecukupan permodalan, juga harus mengaitkan kecukupan modal dengan Profil Risiko Bank. Semakin tinggi risiko bank, semakin besar modal yang harus disediakan untuk mengantisipasi risiko tersebut.

CAR adalah rasio kinerja bank untuk mengukur kecukupan modal yang dimiliki bank untuk menunjang aktiva yang mengandung atau menghasilkan risiko ${ }^{33}$. Tujuannya untuk mengukur kecukupan modal bank

${ }^{29}$ Peraturan OJK No. 8/POJK.03/2014 tentang Penilaian Tingkat Kesehatan Bank Umum Syariah dan Unit Usaha Syariah, Pasal 7 ayat (4)

30 Sugari, Bella Puspita, dkk., Analisis Perbandingan Tingkat Kesehatan Bank Syariah dan Konvensional dengan Menggunakan Metode GREC (Risk Profile, GCG, Earnings, dan Capital), (Purwokerto: Jurnal Ekonomi Bisnis dan Akuntansi, Universitas Jenderal Sudirman, 2015), hlm. 10.

${ }^{31}$ Husein, Arif Rahman, Analisa Perbandingan Pendekatan CAMELS dan RGEC (Studi pada Bank Umum Syariah, (Jurnal Ekonomi Syariah: Teori \& Terapan, 2016), hlm.106.

32 Peraturan Bank Indonesia Nomor 10/15/PBI/2008 tentang Kewajiban Penyediaan Modal Minimum Bank Umum

${ }^{33}$ Kasmir, Bank dan Lembaga Keuangan Lainnya, (Jakarta: Rajawali Press, 2009),

$394 \mid$ JURNAL LISAN AL-HAL 
dalam menyerap risiko/kerugian dan pemenuhan ketentuan KPMM (Kewajiban Penyediaan Modal Minimum) yang berlaku. ${ }^{34}$ Sedangkan kriteria penilaian peringkatnya yaitu sebagai berikut:

Peringkat $1 \quad$ : KPMM $>12 \%$

Peringkat $2: 9 \%<\mathrm{KPMM}<12 \%$

Peringkat $3: 8 \%<\mathrm{KPMM}<9 \%$

Peringkat $4 \quad: 6 \%<\mathrm{KPMM}<8 \%$

Peringkat $5:$ KPMM $<6 \%$

Urutan peringkat faktor Permodalan yang lebih kecil mencerminkan kondisi permodalan bank yang lebih baik ${ }^{35}$.

Dari hasil analisis atas dokumen laporan tahunan empat BUS, diperoleh rasio CAR sebagai berikut:

\begin{tabular}{|c|c|c|c|c|c|c|c|}
\hline No & BUS & 2012 & 2013 & 2014 & 2015 & 2016 & Peringkat \\
\hline 1 & $\begin{array}{l}\text { Bank } \\
\text { Muamalah }\end{array}$ & $11,57 \%$ & $14,05 \%$ & $13,91 \%$ & $12,00 \%$ & $12,74 \%$ & $\begin{array}{l}\text { Peringkat } \\
1\end{array}$ \\
\hline 2 & $\begin{array}{l}\text { Bank } \\
\text { Syariah } \\
\text { Mandiri }\end{array}$ & $13,82 \%$ & $14,10 \%$ & $14,12 \%$ & $12,85 \%$ & $14,01 \%$ & $\begin{array}{l}\text { Peringkat } \\
1\end{array}$ \\
\hline 3 & $\begin{array}{l}\text { Bank BRI } \\
\text { Syariah }\end{array}$ & $11,91 \%$ & $14,49 \%$ & $12,89 \%$ & $13,94 \%$ & $20,63 \%$ & $\begin{array}{l}\text { Peringkat } \\
1\end{array}$ \\
\hline 4 & $\begin{array}{l}\text { Bank BNI } \\
\text { Syariah }\end{array}$ & $19,29 \%$ & $16,54 \%$ & $16,26 \%$ & $15,48 \%$ & $14,92 \%$ & $\begin{array}{l}\text { Peringkat } \\
1\end{array}$ \\
\hline \multicolumn{2}{|r|}{ Rata-Rata : } & $14,15 \%$ & $14,80 \%$ & 14,3 & 13,5 & 15,5 & \\
\hline \multicolumn{2}{|c|}{ Rasio SPS-BUS } & $14,13 \%$ & $14,42 \%$ & $15,74 \%$ & $15,02 \%$ & $15,95 \%$ & \\
\hline
\end{tabular}

Dari data di atas menunjukkan bahwa empat BUS sama-sama memiliki kecukupan modal untuk menunjang aktiva yang mengandung risiko, di atas kewajiban minimal 8\%. Bahkan cenderung meningkat dari tahun 2015 kecuali Bank BNI Syariah yang menurun. CAR BRI Syariah berada pada ranking tertinggi di atas rata-rata CAR BUS keseluruhan.

\section{Simpulan}

Dari pembahasan di atas dapat disimpulkan beberapa hal yaitu: pertama, dari sisi jumlah pembiayaan yang bermasalah (NPF), Bank

hlm. 198.

34 Tim Penyusun, Kodifikasi Peraturan Bank Indonesia: Kelembagaan, Penilaian Tingkat Kesehatan Bank, (Jakarta: Pusat Riset dan Edukasi Bank Sentral, 2012), hlm. 163.

35 Tim Penyusun, Kodifikasi Peraturan Bank Indonesia: Kelembagaan, Penilaian Tingkat Kesehatan Bank, (Jakarta: Pusat Riset dan Edukasi Bank Sentral, 2012), hlm. 163. 
Muamalah Indonesia (BMI) dan BNI Syariah memiliki rasio NPF yang lebih baik dibanding BSM dan BRI Syariah. Tetapi dibanding tahun 2015, ketiga bank umum syariah berhasil menurunkan NPFnya kecuali BNI Syariah.

Kedua, dari sisi rasio Pembiayaan atas Dana Pihak Ketiga (FDR), Bank Muamalah Indonesia memiliki likuiditas lebih tinggi dibanding BSM, BRI Syariah dan BNI Syariah. Bahkan ketiga BUS cenderung menurun dari tahun sebelumnya.

Ketiga, dari sisi rasio kemampuan mengelola aset untuk menghasilkan laba, Bank BNI Syariah memiliki ROA yang lebih tinggi dibanding BMI, BSM, dan BRI Syariah. Tetapi, keempat BUS sama-sama berhasil meningkatkan rasio ROAnya.

Keempat, Dari sisi Kecukupan Modal (CAR), keempat BUS samasama berada pada Peringkat 1. Dengan kata lain, keempat BUS telah memenuhi ketentuan Kewajiban Penyediaan Modal Minimum.

\section{DAFTAR PUSTAKA}

Abdullah, M. Faisal. 2002. Dasar Manajemen Keuangan. Yogyakarta: Universitas Muhammadiyah Malang (UMM) Press.

Agnes, Sawir. 2005. Analisis Kinerja Keuangan dan Perencanaan Keuangan Perusahaan. Jakarta: PT. Gramedia Pustaka Utama

Al Ghifari, dkk. 2015. Analisis Kinerja Perbankan Syariah di Indonesia dan Malaysia dengan Pendekatan Maqasid Indeks. Jakarta: STEI. Jurnal Ekonomi dan Perbankan Syariah, Vol.3 No. 2, Oktober 2015

Arcarya dan Diana Yumanita. 2005. Bank Syariah: Gambaran Umum. Jakarta: PPSK Bank Indonesia

Estes, Ralph. 2005. Tyranny of The Bottom Line: Mengapa Banyak Perusahaan Membuat Orang Baik Bertindak Buruk. (Nur Basuki Rachmanto, Penerjemah). Jakarta: PT. Gramedia Pustaka Utama

Fatwa Majelis Ulama Indonesia (MUI) Nomor 1 Tahun 2004 tentang Bunga (Intersat/Fa'idah)

Fitriana, dkk. 2015. Tingkat Kesehatan Bank BUMN Syariah dengan Bank BUMN Konvensional: Metode RGEC (Risk Profile, Good Corporate Governance, Earning, dan Capital). Pekalongan: Jurnal Ekonomi dan Bisnis. Vol. 17 No. 2. Universitas Pekalongan

Harahap, Sofyan Syafri. 2007. Analisis Kritis Atas Laporan Keuangan. Jakarta: Raja Grafindo Persada

Husein, Arif Rahman. 2016. Analisa Perbandingan Pendekatan CAMELS dan RGEC (Studi pada Bank Umum Syariah. Surabaya: Jurnal Ekonomis

396 JURNAL LISAN AL-HAL 
Syariah: Teori \& Terapan. Universitas Airlangga

Kasmir. 2009. Bank dan Lembaga Keuangan Lainnya. Jakarta: Rajawali Press

Kasmir. 2012. Manajemen Perbankan. Jakarta: Rajawali Press.

Lasta, Heidy Arrvida, dkk. 2014. Analisis Tingkat Kesehatan Bank dengan Menggunakan Pendekatan RGEC. Malang: Jurnal Administrasi Bisnis. Universitas Brawijaya. Vol. 13 No. 2

Matnin. 2016. Kinerja dan Kesehatan Bank Islam. Bangkalan: Jurnal Dinar Ekonomi Syariah. Universitas Trunojoyo Madura

Muhammad. 2005. Manajemen Bank Syariah. Yogyakarta: UPP AMP YKPN

Munawir, S. 2007. Analisa Informasi Keuangan. Yogyakarta: Liberty

Niswatin. 2015. Konsep Dasar Penilaian Kinerja Bank Syariah. Jakarta: Jurnal Ekonomi dan Manajemen.SIEI. Indonesia Banking School

Nurwaty, Etty, dkk. 2014. Umur dan Kinerja Perusahaan: Studi Empiris Perbankan Syariah di Indonesia. Bandung: Research and Knowledge, School of Business and Management. Institut Teknologi Bandung

Nurlela, et. all. 2012. Analisis Perbandingan Kinerja Keuangan pada Perbankan Syariah dengan Perbankan Asing di Indonesia. Lhokseumawe: Jurnal Visioner dan Strategis. Vol. 1 No. 1. Universitas Malikussaleh

Otoritas Jasa Keuangan RI. 2016. Statistik Perbankan Syariah - Desember 2016

Peraturan Bank Indonesia nomor 8/4/PBI/2006 tentang Pelaksanaan Good Corporate Governance Bagi Bank Umum

Peraturan Bank Indonesia nomor 9/1/PBI/2007 tentang Sistem Penilaian Tingkat Kesehatan Bank Umum Berdasarkan Prinsip Syariah

Peraturan Bank Indonesia nomor 10/15/PBI/2008 tentang Kewajiban Penyediaan Modal Minimum Bank Umum

Peraturan Bank Indonesia nomor 13/1/PBI/2011 tentang Penilaian Tingkat Kesehatan Bank Umum

Peraturan Otoritas Jasa Keuangan nomor 8/PJOK.03/2014 tentang Penilaian Tingkat Kesehatan Bank Umum Syariah dan Unit Usaha Syariah

Sugari, Bella Puspita, dkk. 2015. Analisis Perbandingan Tingkat Kesehatan Bank Syariah dan Konvensional dengan Menggunakan Metode GREC (Risk Profile, GCG, Earnings, dan Capital). Purwokerto: Jurnal Ekonomi Bisnis dan Akuntansi. Universitas Jenderal Sudirman

Surat Edaran Bank Indonesia Nomor 13/24/DPNP tahun 2011 tentang Penilaian Tingkat Kesehatan Bank Umum

Tim Penyusun. 2012. Kodifikasi Peraturan Bank Indonesia: Kelembagaan, 
Penilaian Tingkat Kesehatan Bank. Jakarta: Pusat Riset dan Edukasi Bank Sentral.

Umiyati dan Queenindya. (2015). Pengukuran Kinerja Bank Syariah dengan Metode RGEC. Depok: Jurnal Akuntansi dan Keuangan Islam. Vol. 2 No. 2 STEI. SEBI

Undang-undang Nomor 7 Tahun 1992 tentang Perbankan

Undang-undang Nomor 10 Tahun 1992 tentang Perubahan Atas Undangundang Nomor 7 Tahun 1992 tentang Perbankan

Undang-undang Nomor 21 Tahun 1998 tentang Perbankan Syariah 